11. Bodenstein Felicity. Luynes, Honoré d'Albert (duc de). L'Institut national d'histoire de l'art.. URL: https://www.inha.fr/fr/ ressources/publications/publications-numeriques/dictionnaire-critique-deshistoriens-de-l-art/luynes-honore-d-albert-duc-de.html (дата звернення: 26.08.2020).

12. Charles Marville: Photographer of Paris. National Gallery of Art. URL: https://www.nga.gov/exhibitions/2013/marville.html. (дата звернення: 11.08.2020)

13. E. L. D. / E. Le Deley. Dumbarton Oaks Archives Ephemera Collection. URL: https://www.doaks.org/research/library-archives/dumbartonoaks-archives/collections/ephemera/names/e-le-deley (дата звернення: 3.09.2020).

14. Harrrison W. The Heliotype process. Nature journal of science. 1871. № 4. P. 85-87. URL: http://digicoll.library.wisc.edu/cgi-bin/HistSciTech/ HistSciTech-idx?type $=$ div\&did $=$ HISTSCITECH.NATURE18710601.HARRISONPROCESS\&isize=M (дата звернення: 28.05.2020).

15. Mustalish, Rachel A. The development of photomechanical printing procecesses in the late 19th century. Topics in Photographic Conservation. 1997. Vol. 7. P. 73-87. URL: http://resources.culturalheritage.org/ pmgtopics/1997-volume-seven/07_10_Mustalish.pdf (дата звернення: 24.09.2020).

DOI https://doi.org/10.30525/978-9934-26-004-9-63

\title{
СУЧАСНЕ СПРИЙНЯТТЯ ФОТОЗОБРАЖЕНЬ НЮ ПІД ВПЛИВОМ СОЦІАЛЬНИХ МЕРЕЖ
}

\author{
Скорик I. Г. \\ здобувач освіти за освітньо-науковим рівнем доктор філософії \\ Національної академії керівних кадрів культури і мистецтва \\ м. Київ, Украӥна
}

Феномен оголеної фотографії незаперечний - він дає можливість творцям миттєво втілювати будь-які задуми і наочно експериментувати 3 людським тілом, доводячи його до досконалості при збереженні природних пропорцій. Починаючи з середини XX століття і до сьогодні оголена фотографія вирівняла естетичне сприйняття між різними верствами населення, зробивши свою присутність в житті звичним 
явищем. I звівши, притаманний ій еротизм на другий план в критерії оцінки оголеності, зосередивши основний фокус на красі тіла моделі та на та постановці пози. Саме ці параметри в поєднанні з цікавою сюжетною лінією допомагають уникнути «невірного» сприйняття та роблять оголене тіло арт-об`єктом, який в багатьох випадках формує цінність знімка, доводячи його до рівня шедевру. Цей прийом у XX столітті сформував нові напрямки розвитку для фотографії ню, наділивши іiі особливою якістю привертати увагу до тіла моделсй у fashion та рекламної індустрії. В цілому, сучасне мистецтво ню фотографії це - новий погляд на оголену фігуру.

Взагалі, найкращим прикладом, за домопогою якого можна коротко відстежити історію естетичної оголеності це - історія популярного в XX-XXI століття календаря Pirelli, над створенням якого в різні часи працювали найвідоміші фотографи в колаборації 3 моделями та відомими актрисами. При цьому, варто зауважити, що Pirelli ніколи не ставив перед собою завдання епатувати публіку демонстрацією оголених тіл. Навпаки на сторінках календаря спостерігається високопрофесійне арт-ню $з$ мінімальним еротичним ефектом, що відповідає актуальним запитам суспільства, не перетинаючи межу естетизму. Але ця межа дуже тендітна та спірна. Тому сучасні проблеми сприйняття оголених фотографічних зображень мають таку ж суперечливу межу як і в ранні періоди свого формування в окремий напрямок мистецтва. Як зберегти основну цінність та якості подібного твору, котрі автор заклав в основу свого шедевру? Як уникнути руйнування сюжетної лінії, коли демонстрація вічної краси та натхнення - тіло перестає бути привабливим та перетворюється на неякісну спробу довести художній сенс і вплинути на мислення сучасної людини, спотворюючи ії моральні цінності та вносячи хаос в об'єктивну оцінку оголеного зображення? Ці спірні питання не втрачають актуальності та не мають стандартних критеріїв.

Те, що сьогодні ми бачимо відносно оголеної фотографії в таких великих соціальних мережах як Facebook i Instagram не може бути нормою, враховуючи що саме вони $\epsilon$ найвпливовішими «спільнотами», які визначають вкуси та потреби суспільства у всесвітніх масштабах. Фотографи зіткнулись 3 прямою конфронтацією до своєї творчості з боку так званої «спільноти», яка без попередження може видалити їх роботи i навіть цілі сторінки, так як в соціальних мережах існують незрозуміло ким створені «Принципи спільноти», виконання яких контролює алгоритм.

Якщо поглянути на цю проблему з психологічної точки зору, то подібна цензура Facebook та Instagram за допомогою алгоритму підсилює нездорові упередження людини проти оголеного тіла. У свою чергу це 
спричиняє за собою ті ж внутрішні конфлікти, яке людство переживало в періоди заборон, що розірвало практично на генетичному рівні цілісність внутрішнього і зовнішнього світу людини, заразивши його «помилковим соромом». I якщо фотографія може бути надрукована в глянцевому журналі, або висіти на виставковому майданчику чи в музеї, то чому іiі видаляють з сайту? Не хочеться вірити, що сучасне мистецтво оголеної фотографії надовго загрузне в піксельних маскування подібно часів християнських заборон.

Отже, сучасний світ, здатний до новаторства у всіх сферах життя людини, тупцює на місці і створює проблеми у здавалося б цілком природньому питанні - цілісному прийнятті себе індивідом. Хто й навіщо чинить опір гармонійному існуванню людини в оточуючому іiі світі? I чому «першоджерелом зла» є невіддільна людська складова власне тіло.

Припустимо вважати, що це один 3 глобальних «маркетингових» прийомів, котрий ліквідує конкурентні складові для найприбутковіших галузей - Fashion i фарміндустрії, потураючи невгамовному апетиту людини. Тобто вочевидь ми маємо гру із людськими слабкостями. Можливо тому в сучасному світі так багато людей, які не сприймають своє єство, що підвищує рівень затребуваності у різних естетичних операційних методах для вирішення їхніх проблем. А соціальні мережі посилюють цей ефект, породжуючи нові комплекси та психічні розлади. Видаляючи окремі частини тіла за допомогою пікселізації Facebook та Instagram руйнує не тільки сам фото-шедевр, а й здоровий глузд сприйняття красоти тіла.

Ми маємо зворотний ефект.

Мистецтво оголеної фотографії уходить в digital (де можливості необмежені), втрачає здатність дивувати новаторством підходів до демонстрації природньої краси і приймає правила гри «шокувати» «спекулювати» на сокровенному людському інстинкті - сексуальності. Стає не дивним той факт, що сексуальність домінує над сприйняттям оголеного тіла. Сексуальні фото-зображення підкреслено ідеалізовані та зухвало привабливі. Людина попадає в іншу реальність - де тіло об єкт бажання, а його краса не має нічого спільного з тілом наглядача, який перебуває в полоні еротичних ілюзій. Тому не дивно, що у нормальної людини на перший план виходить внутрішня «мораль», яка забороняє все, що пов язано з оголенним тілом на підсвідомому рівні (в свій час цьому активно сприяли релігійні догми).

Джерело такої «моралі» в тому, що внутрішньо людина не готова вважати себе аутсайдером в порівнянні з ідеалами. Все це завдяки тому, що через свою слабкість і небажання побороти ії для досягнення особистої досконалості, людина обирає найпростіший спосіб боротьби 240 
заперечати та забороняти «недосяжне». Ця позиція завжди вигідна тим, хто не прагне прикладати зусиль для власного самоствердження. I заборони соціальних мереж підтримують ці оманливі ідеї - частково приховуючи істину на своїх сторінках і змушуючи шукати більш відверті ресурси. Це дуже недоцільно, тому що Facebook та Instagram - унікальні платформи - джерела найактуальнішої інформації. Саме в цих мережах можливо було б адекватно вирішати подібні спірні питання .

Сдине, що не викликає сумнівів - оголене тіло, безумовно, залишиться джерелом натхнення, а ні сорому. Впевнено припустити, що об`єктивне сприйняття його можливе після подолання потоків суперечливої інформації соцмереж і зміни, нав язаних ними стереотипів. Безумовно адекватна суспільна свідомість до сприйняття зображень ню в естетичному аспекті також стане можливою після того, як цензура в Facebook i Instagram, яка змушує фотографів ховати за пікселями подробиці фізіології, піде до забуття. По-перше для того, щоб оголена фігура нарешті повернулася до справжньості та натуральністі в ракурсі стандартів і правил. По-друге, щоб людська свідомість по достоїнству оцінювала велич дару природи - красивого оголеного тіла без заборон і «пікселізації». I стандарти естетичності арт-об єкту чітко визначили межу моралі та сексуальності. I, нарешті по-третє, щоб наступні покоління мали можливість вільно милувалися фото шедеврами сучасності, як ми спадщиною, яка дісталася від наших предків.

\section{Література:}

1. Бекус Н. Эротика взгляда: фотография или тело. [Електронний pecypc]. - Режим доступу: http://photoscope.iatp.by/critic4.html

2. Бодрийяр Ж. Фотография или письмо света. [Електронний pecypc]. - Режим доступу : http:wwh.nsys.by/klinamen/dunaev 1 .html

3. Газарова Е. Гламурная телесность. [Електронний ресурс]. Режим доступу: http://www.psynavigator.ru/articles.php?code=361

4. Деготь Е. Тело в фотографии. [Електронний ресурс]. - Режим доступу:

http://www.mdf.ru/exhibitions/today/2002/bodyandmotion/press54.html

5. Король Д. Лезвие фотографа. [Електронний ресурс]. - Режим доступу: http://photoscope.iatp.by/critic.html\#lezv

6. Леви Т.С. Психология телесности в ракурсе личного развития. [Електронний ресурс]. - Режим доступу : http://telesnost.ru/omega/ psihologiya/

7. Плотичкина Н. Тело и телесность в молодежной культуре. [Електронний ресурс]. - Режим доступу: http://utopiya.spb.ru/ index.php?option=com_content\&view=article \&id=1303:2010 -11-28-16-23$14 \&$ catid=84:2010-11-28-14-00-55\&Itemid $=136$ 
8. Суворова О. С. Телесность человека как основа его жизни и единства с природой. [Електронний ресурс]. - Режим доступа : http://www.philosophy.nsc.ru/disc/iphras/library/wbiof0.html

9. Сьюзен Сонтаг «О фотографии» Перевод с английского В. Голышева, Ад Маргинем Пресс УДК 77.0ББК85.160С62 [Электронный ресурс]. - Режим доступу: https://www.rulit.me/books/ofotografii-read-280021-1.html

10. Уилсон Е. Облаченные в мечты: мода и современность / пер. с англ. Е. Демидовой, Е. Караш, Е. Яминой. Москва : Новое литературное обозрение, 2012. 288 с. (Библиотека журнала «Теория моды»).

11. Kelsey Ables «The Photographers Fighting Instagram's Censorship of Nude Bodies» Visual Culture [Электронный ресурс] https://www.artsy.net/article/artsy-editorial-photographers-fightinginstagrams-censorship-nude-bodies?utm_medium= social\&utm_source=facebook\&utm_campaign=editorial

DOI https://doi.org/10.30525/978-9934-26-004-9-64

\title{
АНАЛІЗ СТРУКТУРИ КОМПОЗИЦІї МОЗАЇКИ М. СТОРОЖЕНКА «УКРАЇНА СКІФСЬКА - ЕЛЛАДА СТЕПОВА»
}

\author{
Соловей О. В. \\ дочент кафедри живопису $і$ композииії, \\ виконувач обов'язків завідувача кафедри живопису та композиціі \\ Національної академії образотворчого мистецтва і архітектури \\ м. Київ, Україна
}

Микола Стороженко своїм творами - графічними, станковими, монументальними - незмірно збагатив мистецьку скарбницю України. Його монументальне мистецтво поліфонічне, здатне створювати багатовимірну дію надзвичайно потужної енергетичної сили, проявляти єдиний образ, що поєднує індивідуальний світ зі світом духовним, космічним.

Монументальні роботи митця складні, багатопланові за своїм просторовим та образним вирішеннями, глибинною змістовністю, що зумовлено його духовно-філософським світоглядом. Він застосовує оригінальні авторські техніки, неординарні формально-композиційні рішення, майстерно поєднані зі специфікою образного ладу. Останнім 242 